\title{
The Constitution of Canada as Supreme Law: A New Definition
}

\section{Maxime St-Hilaire, Patrick F. Baud and Elena S. Drouin ${ }^{\star}$}

Not only is there no clear answer in Canadian law as to what the 'supreme law' of Canada comprises, but no agreement on how to find that answer. In this short paper, we claim to solve the problem by proposing a new, workable, definition of the Canadian Constitution as supreme law that discards the document list approach of subsection 52(2), Constitution Act 1982, in favour of one that, through subsection 52(3), is based on the constitutional amendment procedure of Part V, which relates to provisions.

Canada's Constitution has for many decades become best known for its combining British-style constitutional monarchy and parliamentary democracy with American-inspired federalism, albeit in a colonial form. Such a mixed constitution would have been considered improbable by the constitutional scholars of that age, such as A.V. Dicey. ${ }^{1}$

The Canadian federation's Constitution, which was initially set out in Canada's Constitution Act, 1867 (CA 1867) served as a model for the Commonwealth of Australia Constitution $A c t^{3}$ in 1901. Over three decades ago, the Canada Act $1982^{4}$ and its Schedule B, the English and French versions of the Constitution Act, 1982 (CA 1982), ${ }^{5}$ transferred full and exclusive constituent competency to Canada. This final step in Canada's peaceful transition from British colony to independent country continues to serve as a model throughout the Commonwealth. Yet the constitutional reforms brought about in 1982 continue to raise the following essential, theoretical question: how, absent a revolution, can the full constituent competency be truly transferred rather than simply delegated to the former colony by the imperial legislator?

The CA 1982 also brought major reforms to Canada's Constitution. In the past 35 years, Canada has become renowned for its Charter of Rights and Freedoms, ${ }^{6}$ which served as one of the models for the Israeli Basic Laws ${ }^{7}$ and for South Africa's Bill of Rights, ${ }^{8}$ among others. ${ }^{9}$ The CA 1982 also brought the recognition and affirmation of Aboriginal and treaty rights in section 35 , which currently informs ongoing Australian debates on the constitutional recognition of Aboriginal and Torres Strait Islander peoples.$^{10}$ But these oft-debated features of Canada's Constitution mask a more fundamental problem facing Canadian constitutionalists - they cannot answer what should be a simple question: what is the supreme law of Canada composed of?

\section{We can't even agree on how to find out what the supreme law is}

The question of what the supreme law of Canada is composed of is one without a clear answer in Canadian law. There exists no reliable list of the supreme law's components and no such list could be established. Rather, it seems that the supreme law of Canada includes any possible provision that, based on the nature of its contents, falls under one of the (real) constitutional amendment procedures that the supreme law provides in certain of its key components. However, one of the amendment procedures does not specify which contents it applies to, yet it presents itself as the "normal," that is to say, residual 
or default procedure. This draws a vicious circle. In our view, this problem is one that should be of interest not only to Canadian constitutionalists. It also highlights the issues that can arise from perfectible constitutional drafting and the interaction between the constitutional amendment procedure and the rest of a constitution, notably a federative one.

\section{A basic question with no clear answer (yet), but a clue in the enshrining of the concept of "supreme law"}

Subsection 52(1) of the CA 1982 "enshrines" the concept of supreme law into Canadian law, that is, of the "Constitution of Canada" as supreme law of this country, providing that "any law that is inconsistent with the provisions of the Constitution is, to the extent of the inconsistency, of no force or effect." 11 The French version uses the word "inopérantes." 12 This is very unfortunate, because in Canadian federalism and distribution of powers jurisprudence - we do not use the single word "power" to refer to a legal power, just as we care about the distinction between the ideal of a (political) constituent power ${ }^{13}$ and that of a (legal) constituent competency - the term "inopérant" does not mean "invalid." 14 To be sure, no later than 1985, the Supreme Court of Canada made clear in an opinion that "manner and form" requirements prescribed by the supreme law had not been met, that " $[t]$ he words 'of no force or effect' [or 'inopérantes']" in section 52 of the $C A$ 1982, "mean that a law thus inconsistent with the Constitution has no force or effect because it is invalid." 15

\section{A provision that is misleadingly underinclusive}

Subsection 52(2) of the CA 1982 states that the "Constitution of Canada," so understood as Canada's supreme law, "includes (a) the Canada Act 1982, including [the Constitution Act, 1982]; (b) the Acts and orders referred to in the schedule [to the Constitution Act, 1982, including the Constitution Act, 1867]; and (c) any amendment to any Act or order referred to in paragraph $(a)$ or $(b) .{ }^{\prime \prime 6}$ Does subsection 52(2) mean that the legal, but supra-legislative Constitution of Canada is to be exhaustively found in these Acts and orders, as amended? No, it does not.

Let us first recall that the "supreme law" is only the "written" (as opposed to the "unwritten," jurisprudential) element of the legal Constitution in the formal, that is, supra-legislative sense. But then it must be recognized that the supreme law so properly - and strictly - understood does not correspond with what subsection 52(2) of the $C A$ 1982 says it includes. ${ }^{17}$ For more than 20 years, it seemed well understood that the Supreme Court of Canada did not clearly rule out the possibility that the supreme law might include provisions other than those referred to by subsection 52(2) of the CA 1982 (through its Schedule). ${ }^{18}$ But, in its 2014 opinion on sections 5 and 6 of the Supreme Court Act, ${ }^{19}$ the Court confirmed that provisions of this very Act that relate to the Court's "essential features" are part of the supreme law. ${ }^{20}$ While the Supreme Court Act is not referred to in subsection 52(2) or in the Schedule to the CA 1982, the Court reached its conclusion by virtue of the constitutional amendment procedure prescribed by the $C A 1982$. This procedure deals specifically with the "composition of the Supreme Court of Canada" - a category held by the SCC to include "the continued existence of the Court"21 - and more generally, "the Supreme Court of Canada" - a category held by the SCC to include, "at the very least, the Court's jurisdiction as the final general court of appeal for Canada, including in matters of constitutional interpretation, and its independence"22 - at paragraphs $41(d)$ and $42(1)(d)$, respectively. This means that it is not subsection 52(2), but the constitutional amendment procedure, in the CA 1982, that determines whether or not a given provision is part of the supreme law of Canada.

\section{A provision that is also misleadingly overinclusive}

Indeed, subsection 52(2) of the CA 1982 is all the less useful in identifying the supreme law's contents when we consider how many provisions included in the instruments it refers to do not belong to the supreme law as properly understood: that is, in a way that makes sense given different legal effects. This is because many such provisions may be amended or repealed by 
ordinary legislation enacted by a regular legislator, notably under sections 44 or 45 of the $C A$ 1982. It is contingent, if not unfortunate, that the latter sections have been put into Part $\mathrm{V}$ of the CA 1982, titled "Procedure for Amending Constitution of Canada." ${ }^{23}$ Their predecessor provisions, subsections 91(1) - its 1949-introduced version $^{24}$ - and 92(1) of the CA 1867 rightly appeared in Part VI of that Act, titled "Distribution of Legislative Powers." ${ }^{25}$ Unlike most other sections in Part V of the CA 1982, sections 44 and 45 do not provide, or participate in the provision, of a special, constraining, and ad hoc procedure. Instead, they simply confer jurisdiction to those regular legislators that are the federal Parliament and the provincial legislatures. They plainly read:

\footnotetext{
"44. Subject to sections 41 and 42, Parliament may exclusively make laws amending the Constitution of Canada in relation to the executive government of Canada or Senate and House of Commons.

45. Subject to section 41 , the legislature of each province may exclusively make laws amending the constitution of the province." ${ }^{26}$
}

Although the Supreme Court of Canada is perfectly aware that some provisions referred to in subsection 52(2) of the CA 1982 can be amended or repealed by ordinary legislation under section 44 or 45 of the same Britishimperial/supreme-law-belonging Act, the Court still refers to them as though they were part of the "Constitution of Canada" for the purposes of subsection 52(1), that is, the supreme law of Canada. $^{27}$

As a result of its blind fidelity to the wording of the CA 1982 and its particularly misleading subsection 52(2), the Supreme Court's lack of both a theoretical and a practical understanding of what makes the difference between ordinary law and supreme law has it uselessly struggling in New Brunswick Broadcasting with the trap, for instance, of whether provisions that are not referred to in subsection 52(2), but are part of the "constitution of the province" for the purpose of section 45, are part of the "Constitution of Canada" and therefore the supreme law of Canada under subsection 52(1). ${ }^{28}$ Even when dealing with provisions that both fall under section 44 or 45 of the CA 1982 and that are undoubtedly part of an instrument referred to by subsection 52(2), the Court falls into the trap. This is what happened in Eurig Estate (Re), where Justice Major wrote the majority reasons - and was not contradicted by the dissenting or concurring opinions on this particular point. ${ }^{29}$ Justice Major took for granted that, because the provincial legislatures' competency over the "constitution of the province" had been moved from the federative distribution of competencies in the $C A$ 1867 to a part of the $C A 1982$ titled "Procedure for Amending Constitution of Canada", it had to be read "in association with [sub] section 52(1)" of the [CA 1982], as if it had changed from being a merely substantive constitutional competency to being a formal one. ${ }^{30}$ This led Justice Major to "read in" an (express) "form requirement" into section $45 .^{31}$ It is symptomatic of his falling into the trap that Justice Major explained the existence of contradicting comments by Justice Pigeon in the Reference re Agricultural Products Marketing Act $^{32}$ by mentioning the fact that they "were made before the passage of the 1982 amendments to the Constitution." ${ }^{33}$ Yet, while what is covered by section 45 may be considered "constitutional law" in the substantial sense of the expression, it belongs, in (formal) essence, to ordinary law, which, by definition, cannot be part of the supreme law. ${ }^{34}$

We submit Eurig Estate is incorrect on this point and should not be followed. No particular form beyond passage by the Senate and House of Commons or the legislative assembly of the province and royal assent by the Governor General or the Lieutenant Governor, as the case may be, is required. ${ }^{35}$ That was the case before 1982 , as neither subsection 91(1) nor 92(1) required the use of a particular form to amend the constitutional provisions to which they applied. As the Supreme Court noted in its 2014 opinion on the reform of the Senate, sections 44 and 45 are the successors of those provisions and there was no intention in 1982 to do anything more than preserve the powers that subsections 91(1) and 92(1) conferred. It is notable, though not decisive, that Eurig Estate was not cited in the Supreme Court's discussion of sections 44 and 45 in its opinion on the reform of the Senate. ${ }^{36}$ 
If Eurig Estate was good law, and set out a rule such that if the federal Parliament or a provincial legislature failed to expressly amend (or repeal) a provision, the amendment (or repeal) would be invalid, we expect that the Supreme Court would have taken the opportunity to remind legislators of this point.

\section{A shift from a substantive to a procedural criterion}

As a result of the foregoing, we must not only discard subsection 52(2) of the CA 1982 in favour of a procedural criterion for determining whether a given provision is part of the supreme law of Canada, but also reject from this criterion sections 44 and 45, even though they appear in Part V, whose title suggests that its provisions are entirely devoted to the constitutional amendment procedure.

By the same rationale, we have to include section 35.1 of the CA 1982 in the procedural criterion, even though it is not only likely non-justiciable, but it is also found in a part other than Part V, that is, Part II, titled "Rights of the Aboriginal Peoples of Canada." ${ }^{37}$ Section 35.1 provides that:

The government of Canada and the provincial governments are committed to the principle that, before any amendment is made to Class 24 of section 91 of the 'Constitution Act, 1867', to section 25 of this Act or to this Part,

(a) a constitutional conference that includes in its agenda an item relating to the proposed amendment, composed of the Prime Minister of Canada and the first ministers of the provinces, will be convened by the Prime Minister of Canada; and

(b) the Prime Minister of Canada will invite representatives of the aboriginal peoples of Canada to participate in the discussions on that item. ${ }^{38}$

Section 35.1 was added to Part II of the CA 1982 in 1983 by an amendment made under the general procedure, ${ }^{39}$ which is mostly provided for by section 38 of the CA 1982 and requires, among other things, the approval of two-thirds of the provinces representing 50 percent of the total population of the provinces. ${ }^{40}$
Although section 35.1 undoubtedly concerns the rights of Aboriginal peoples, it was likely added to Part II in an attempt to avoid the application of paragraph $41(e)$, which requires, among other things, the unanimity of the provinces to amend Part V. In its opinion on the Senate reform, the Supreme Court concluded that, given the Senate's role in the constitutional amendment procedure set out in Part V, its abolition, even if it left the text of Part V intact, would (more than incidentally) alter the functioning of the procedure and therefore falls under paragraph 41(e). Generalizing from the Supreme Court's conclusion, paragraph 41(e)'s purpose is to protect the functioning of the constitutional amendment procedure and, absent the unanimity of the provinces, prevents the addition or removal of requirements for making constitutional amendments. ${ }^{41}$ Since section 35.1 seems to add a requirement for the making of a constitutional amendment to certain specified provisions relating to Aboriginal peoples and was not added with the unanimous approval of the provinces, we have reason to doubt its validity; this amendment appears to be unconstitutional. ${ }^{42}$

Section 35.1 is a further example, in a pool of many, of the careless drafting of the CA 1982. Our point here is that, because the defining criterion of the supreme law of Canada has to be procedural, its general principle is to be found in subsection 52(3) of the CA 1982, which provides that " $[\mathrm{a}]$ mendments to the Constitution of Canada [so understood] shall be made only in accordance with the authority contained in the Constitution of Canada." ${ }^{33}$ This principle, and by extension, the declaration that the Constitution is the "supreme law of Canada" in subsection 52(1), are integral to the constitutional amendment procedure and likely fall under paragraph $41(e)$. In some sense, paragraph $41(e)$ is the ultimate constituent competency for Canada the power to amend the constitutional amendment procedure - and thus the de jure sovereign in Canada. In the next two sections, we will examine the procedure in greater detail to see what it can tell us about what is and is not part of the supreme law of Canada. 


\section{It is the (unknown) sum of all provisions that can be amended, repealed or enacted only under the (known) amendment procedure it provides}

In Canadian constitutional law, it is not tautological to say, as we just did, that, as provided by subsection 52(3) of the $C A 1982$, the supreme law of Canada is composed of all provisions that may be only amended in accordance with it. This is precisely what makes the difference between (formally) ordinary and (formally) constitutional "written" laws - an ordinary law cannot definitively determine how it is to be amended. While it is true that we do not know the exact substantive extent of the supreme law of Canada, we do know that the constituent competency (which again, must not be mistaken for the idea of "constituent power"), which was transferred to Canada in 1982 through an amendment "formula," is meant to be exhaustive, or as Richard Albert puts it, a "complete code." 44 This is what the "patriation of the Constitution" - effected by the Canada Act $1982^{45}$ and its Schedule B, the CA 1982 - was chiefly about. ${ }^{46}$ This means, as the Supreme Court explained in its 1982 opinion rejecting Quebec's claim that it possessed a conventional veto over constitutional amendments, the "new procedure for amending the Constitution of Canada... entirely replaces the old one in its legal as well as in its conventional aspects." ${ }^{47}$ It is through subsection 52(3), which we propose to use as the criterion for defining the supreme law of Canada that allows us to conceive of the nonrecognition by, ${ }^{48}$ or "irrelevance" for, ${ }^{49}$ Canadian law, of the hypothetical repeal by the Parliamentary of the United Kingdom of section 2 of the Canada Act 1982. This section reads: "[n]o Act of the Parliament of the United Kingdom passed after the Constitution Act, 1982 comes into force shall extend to Canada as part of its law." ${ }^{50}$

Any provision elsewhere in the supreme law related to constitutional amendment procedure is implied to have been repealed by Part V of the CA 1982. We are aware of five such provisions: section 3 of the Constitution Act, $1871,{ }^{51}$ which allowed the federal Parliament to alter a prov- ince's boundaries only with the authorization of the affected province's legislature; the provisions in each of the agreements, made between the Federal executive and those of Alberta, British Columbia, Manitoba, and Saskatchewan concerning public lands and natural resources of these four provinces; and put into law and constitutionalized by the British/imperial Constitution Act, 1930, which reproduced them in schedules that allow those agreements to be "varied by agreement confirmed by concurrent statutes of the Parliament of Canada and the Legislature of the Province." 52

\section{The supreme law of Canada: a new, procedural definition}

We can therefore define the content of the supreme law of Canada as being composed of all the "written" law: that is, the legal provisions, whose amendment, repeal or enactment now (and since April 17, 1982) ${ }^{53}$ fall under the constituent competency that is established by the true and variable constitutional amendment procedure established by the CA 1982. As we said, this procedure is mostly provided for in Part $\mathrm{V}$ of the CA 1982, but includes section 35.1, which is in Part II of the CA 1982, and excludes sections 44 and 45, which are in Part V. That said, this article is not the best venue to detail the constitutional amendment procedure and the ongoing complex (and complicated) jurisprudential and academic debates it generates.

\section{The Canadian constitutional amendment procedure: a new, functional identification}

To sum up, we would say that in Canada, the formal and real constitutional amendment procedure, and thus the formal and real constituent competency, breaks down into three different procedures. Two of them apply in specific instances, while the other is intended to be the "normal," that is, default or residual procedure, which (as we said before and will get back to in the next part) creates a loophole. This gives the courts considerable leeway to determine whether certain provisions come under one or more of the federally distributed, regular legislative competencies or the formal constituent competency. 
An alternative (and probably better) way to describe the constituent competency is to say that there is only one procedure, in which the Governor General proclaims the amendment under the Great Seal of Canada ${ }^{54}$ with the authorization of the House of Commons, possibly the Senate (whose opposition can be overridden), ${ }^{55}$ and a variable number of provincial legislative assemblies.

These are the key actors whose coordinated action forms Canada's constituent competency. The authorizing actors (that is, all except the Governor General) are equally vested with the right to formally initiate the constitutional amendment procedure under section 47 of the CA $1982 .{ }^{56}$

Part V and section 35.1 of the CA 1982 refer to other actors, but those actors do not, in our opinion, play a role in either authorizing or proclaiming amendments. For example, section 48 of the CA 1982 refers to the Queen's Privy Council for Canada, a body established by virtue of section 11 of the CA 1867, but only to bind it to "advise the Governor General to issue a proclamation...forthwith on the adoption of the resolutions required for an amendment." ${ }^{57}$ Assuming for the sake of argument that it is valid, section 35.1 of the CA 1982 unclearly, weakly, and probably unjusticiably requires the convening of a "constitutional conference" before the initiation of the procedure for an amendment of specified provisions that directly relate to the Aboriginal peoples of Canada. Section 49 of the CA 1982, now obsolete, provides for a mandatory constitutional conference "to review" the provisions of Part V within 15 years of its coming into force. ${ }^{58}$ Surprisingly, both sections 35.1 and 49 refer to actors who have historically had a political or conventional existence, but not a legal one: the provincial first ministers and the "Prime Minister of Canada." 59 Finally, the Supreme Court's 1998 opinion on the domestic and international law surrounding the possible secession of Quebec unclearly (and problematically ${ }^{60}$ ) made the federal and provincial executives somehow legally bound actors in Canada's constituent competency, using following terms:
The Constitution Act, 1982 gives expression to this [democratic] principle, by conferring a right to initiate constitutional change on each participant in Confederation. In our view, the existence of this right imposes a corresponding duty on the participants in Confederation to engage in constitutional discussions in order to acknowledge and address democratic expressions of a desire for change in other provinces. This duty is inherent in the democratic principle which is a fundamental predicate of our system of governance. ${ }^{61}$

In summary, the threefold real and formal procedure to amend, repeal or enact provisions of the supreme law of Canada consists in the issuance of a proclamation by the Governor General, so authorized by at least the lower house of the federal Parliament and a variable number of provincial legislative assemblies. In the next part, we will suggest a way to map out this procedure.

\section{How to better define the procedure that enables the supreme law's identification and amendment}

Building on this better, procedural understanding of what the supreme law of Canada is, we now want to clarify how one can also better define the procedure that allows for its amendment. Indeed, it is this procedure that, as we submitted, represents the best criterion to determine whether or not a provision is part of this very supreme law.

\section{The Canadian constitutional amendment procedure: a new, 'thought-economical', account}

Canada's constitutional amendment procedures are mostly set out in Part V of the CA 1982. They are asymmetrical, composed of a default, or "normal" procedure and two specific, or "exceptional" ones. We will start with the two exceptions.

The first and most onerous of all three procedures resides in the combination of sections 41 (necessary authorizations), 46 (initiative and revocation of authorization), 47 (overriding of the Senate's failure to authorize an amendment by the House of Commons), 48 (Privy Council's 
duty to advice the Governor General to issue the proclamation), and, most likely subsection 39(2) (imposing a three-year time limit starting with the first authorizing resolution). It is the most burdensome procedure because it requires the authorization of all ten provincial legislative assemblies. According to section 41, this procedure applies to amendments in relation to:

(a) the office of the Queen, the Governor General and the Lieutenant Governor of a province; $\left[{ }^{62}\right]$

(b) the right of a province to a number of members of the House of Commons not less than the number of Senators by which the province is entitled to be represented at the time this Part comes into force;

(c) subject to section 43, the use of the English or the French language;

(d) the composition of the Supreme Court of Canada $\left[{ }^{63}\right]$; and

(e) an amendment to this Part. ${ }^{64}$

The second specific procedure is provided for by the combination of sections $43,46,47$, 48, and, arguably, subsection 39(2). Unlike the first procedure, it is considerably less demanding than the default procedure (which we will detail below). The only legislative assembly whose authorization it requires is that of "each province to which the amendment applies." 65 This could very well be only one province. The procedure applies to amendments "in relation to any provision that applies to one or more, but not all provinces, including $(a)$ any alteration to boundaries between provinces, and $(b)$ any amendment to any provision that relates to the use of the English or the French language within a province." 66 Section 43 has not only been used to amend existing provisions of the supreme law, but also to enact one: section 16.1 of the Charter, which guarantees that " $\mathrm{t}]$ he English linguistic community and the French linguistic community in New Brunswick have equality of status and equal rights and privileges, including the right to distinct educational institutions and such distinct cultural institutions as are necessary for the preservation and promotion of those communities." ${ }^{67}$
The third and final constitutional amendment procedure presents itself as the "normal" or default one. It is determined by the combination of sections 38, 39 (subsection 39(1) creates a one-year waiting period and subsection 39(2) creates a three-year time limit), 40 (compensation resulting from certain amendments), 42, 46, 47, 48, and arguably, section 35.1 (amendments to provisions regarding Aboriginal Peoples) of the CA 1982 - assuming, for the sake of the argument, it is valid, and if so, justiciable.

Many Canadian constitutionalists approach section 42 , and its intrinsic connection with section $38(1)$ and sections $39,46,47$, and 48 , as if it were a distinct amendment procedure. It is also possible, and perhaps more "Occamian," to understand section 42 as an adjustment of the default procedure for specified matters. Indeed, subsection $42(1)$ refers to $38(1)$, the latter of which provides for the central elements of the default procedure, making it clear that subsection 38(1) applies to an amendment "in relation to the... matters" set out in subsection 42(1):
(a) the principle of proportionate representation of the provinces in the House of Commons prescribed by the Constitution of Canada $\left[{ }^{68}\right]$; (b) the powers of the Senate and the method of selecting Senators $\left[{ }^{69}\right] ;(c)$ the number of members by which a province is entitled to be represented in the Senate and the residence qualifications of Senators $\left[{ }^{70}\right]$; $(d)$ subject to paragraph 41(d), the Supreme Court of Canada $\left[{ }^{71}\right] ;(e)$ the extension of existing provinces into the territories $\left[{ }^{72}\right]$; and $(f)$ notwithstanding any other law or practice, the establishment of new provinces $\left[{ }^{33}\right] .^{74}$

According to section 42(2), subsections 38(2) to (4) - which, for an amendment "that derogates from the legislative powers, the proprietary rights or any other rights or privileges of the legislature or government of a province," 75 require an absolute majority of the members of a legislative chamber for a resolution of assent to be passed and grant a (revocable) right to withdraw - do not apply to amendments that fall under subsection $42(1){ }^{76}$

More demanding than the "bilateral" special procedure of section 43 , but less stringent than 
the "unanimity" special procedure of section 41 , this normal procedure requires the authorization of "the legislative assemblies of at least twothirds of the provinces that have, in the aggregate, according to the then latest general census, at least fifty per cent of the population of all the provinces," in addition, of course, to the authorization of the House of Commons, the Senate (whose failure to authorize an amendment may be overridden by the Commons), and the issuance of a proclamation by the Governor General. ${ }^{77}$ Subsection 38(1) refers to the total "population of all the provinces" which is smaller than Canada's population, excluding the population of the territories, which may not participate in the constituent competency. ${ }^{78}$

\section{A problematically overlooked loophole}

In the absence of any conceivable, complete list of the provisions that might be included in the supreme law of Canada, the presence (within this list) of a residual constitutional amendment procedure, in addition to specific ones, jeopardizes what should otherwise have been a quite efficient procedural criterion for identifying such provisions. Indeed, after determining that a proposed enactment does not come under the ambit of either special procedures under sections 41 and 43 or any of the specified instances of application of the adjusted "normal" procedure under section 42 , one is, as long as the proposed enactment's substance is somehow "constitutional" in nature, dealing with government or rights, left with the question of whether this enactment is within the jurisdiction of one of the regular legislators, and thus a matter of (formally) ordinary legislation, or is within the ambit of subsection 38 (1) of the CA 1982, and thus a matter of (formally) constitutional legislation.

Since Canada is a federation, one might be tempted to think that the solution to the problems created by Canada's confusing constitutional amendment procedure lies in checking whether the proposed enactment comes within the ambit of one of the distributed legislative competencies between the federal Parliament and provincial legislatures, including those provided in sections 44 and 45 of the CA 1982. There is a snag. Like any federation, whose definition of legislative heads of power must be exhaustive, Canada has a supreme law that provides for a residual legislative competency. In Canada, that competency is conferred on the federal Parliament by the opening words of section 91 of the $C A$ 1867, with the relative exception of subsection 92(16) of the CA 1867, which confers exclusive jurisdiction to provincial legislatures over "[g]enerally all Matters of a merely local or private Nature in the Province." 79

By imposing limits to the federal residual legislative competency - setting aside its "emergency branch," 80 the judicially recognized competency to alter the federative division of competencies in emergency situations - the "national dimensions branch" should have resolved this problem by providing a criterion to determine whether a given provision falls under this formally ordinary federal legislative competency. ${ }^{81}$ If it does not fall under the residual legislative competency, then the provision falls under the residual constituent competency under subsection 38(1) of the CA 1982. However, the national dimensions doctrine seems to be falling, if it has not already fallen, into oblivion, as it has not even been pled in recent division of competencies cases. Consequently, in our opinion, the trial judge in the case challenging the Succession to the Throne Act ${ }^{82}$ currently on leave to appeal at the Quebec Court of Appeal, failed to consider whether the federal statute validly fell under the federal residual legislative competency under the opening words of section 91 of the CA 1867 or required an amendment under the residual constituent competency under section 38 of the $C A$ 1982, making it therefore invalid. ${ }^{83}$

The question of whether an enactment is subject to section 38 of the $C A 1982$ does not always arise as a choice between this latter section and the opening words of section 91 of the CA 1867. This question can also arise with sections 44 or 45 of the CA 1982. In the Senate Reform Reference, for instance, the Supreme Court of Canada unanimously concluded that, despite the seemingly clear wording of section 44 of the CA 1982 - which reads "Subject to sections 41 and 42, Parliament may exclusively make laws amending the Constitution of Canada in relation to the 
executive government of Canada or the Senate and House of Commons" ${ }^{4}$ - changes "engaging the interests of the provinces in the Senate as an institution forming an integral part of the federal system" have an impact on the Senate's "fundamental nature role." ${ }^{55}$ Thus, they may only be made under the residual constitutional amendment procedure under section $38 .{ }^{86}$ Ultimately, this final case is striking evidence of the enormous power given to the courts to determine, ad hoc, a very fundamental question of positive Canadian law. This power, however, is the result, not only of the poor drafting and "architecture" of the CA 1982 - the ensuing problems of which we hope our doctrinal approach might help remedy - but also of the Supreme Court's approach to interpreting Part V. As to its concurrence with the federal residual competency, this approach to the residual constitutional amendment procedure adds a concurrence with the federal competency over the executive government of Canada or the Senate and House of Commons, which presents itself clearly as to apply "residually" to these specified matters. ${ }^{87}$

\section{Endnotes}

* Maxime St-Hilaire is associate professor of law at the Université de Sherbrooke. He wishes to thank the students in his constitutional law courses contributing to the development of the arguments made in this article, as well as Laurence BichCarrière for helping to develop and present many of these arguments in more fragmentary form in "La constitution juridique et politique du Canada : notions, sources et principes", in JurisClasseur Québec, Droit constitutionnel, Droit public collection (Montreal, LexisNexis: 2011; latest update: 2015), booklet 1 .

Patrick F. Baud received his law degrees with honours from McGill University.

Éléna S. Drouin BCL/LL.B. candidate at McGill University's Faculty of Law. She currently works as a research assistant for the Peter MacKell Chair in Federalism. This article does not necessarily reflect the views of her employer

1 AV Dicey, Introduction to the Study of the Law of the Constitution, 8th ed (Indianapolis: Liberty Classics, 1915) at 73.
2 Constitution Act, 1867 (UK), 30 \& 31 Vict, c 3, reprinted in RSC 1985, Appendix II, No 5 [CA 1867].

3 Commonwealth of Australia Constitution Act 1900, (UK), 63 \& 64 Vict, 1900, c 12.

4 Canada Act, 1982 (UK), 1982, c 11 [Canada Act, 1982].

5 Constitution Act, 1982, being Schedule B to the Canada Act 1982 (UK), 1982, c 11 [CA 1982].

6 Canadian Charter of Rights and Freedoms, Part I of the Constitution Act, 1982, being Schedule B to the Canada Act 1982 (UK), 1982, c 11 [Charter].

7 Lorraine Weinrib, "The Canadian Charter as a Model for Israeli’s Basic Laws" (1993) 4:3 Const Forum Const 85 at 85-87.

8 Constitution of the Republic of South Africa, 1996, ch 2.

9 David S Law \& Mila Versteeg, "The Declining Influence of the United States Constitution" (2012) 87:3 NYUL Rev 762.

10 Recognising Aboriginal and Torres Strait Islander Peoples in the Constitution: Report of the Expert Panel (Canberra: Commonwealth of Australia, 2012) at 52, 93 <https://www.pmc.gov.au/ sites/default/files/publications/RecognisingAboriginal-and-Torres-Strait-Islander-Peoplesin-the-constitution-report-of-the-expert-panel_0. pdf $>$.

11 Charter, supra note 6, s 52(1).

12 "Inopérant" (inoperative) has a distinct meaning in Canadian federalism and division of powers jurisprudence: where a federal law is paramount over a provincial law, the provincial law remains valid, but is in abeyance as long as the federal law remains in force. See Quebec (Attorney General) $v$ Canadian Owners and Pilots Association, 2010 SCC 39 at para 62, [2010] 2 SCR 536, citing Rothmans, Benson \& Hedges Inc v Saskatchewan, 2005 SCC 13 at para 11, [2005] 1 SCR 188.

13 See Nicolás Figueroa, "I•CON Debate Review: Constituent Power and Constitutional Revolution" (25 February 2016), International Journal of Constitutional Law Blog, online: <www. iconnectblog.com/2016/02/i•con-debate-reviewby-Nicolas-Figueroa $>$.

14 See Quebec (Attorney General) v Lacombe, 2010 SCC 38, [2010] 2 SCR 453.

15 Re Manitoba Language Rights, [1985] 1 SCR 721 at 746, 19 DLR (4th) 1.

16 CA 1982, supra note 5, s 52(2).

17 See New Brunswick Broadcasting Co v Nova Scotia (Speaker of the House of Assembly), [1993] 1 SCR 319, 100 DLR (4th) 212 [New Brunswick Broadcasting]; Reference re Remuneration of 
Judges of the Provincial Court of Prince Edward Island; Reference re Independence and Impartiality of Judges of the Provincial Court of Prince Edward Island, [1997] 3 SCR 3, 150 DLR (4th) 577 ; Reference re Secession of Quebec, [1998] 2 SCR 217, 161 DLR (4th) 385 [Quebec Secession Reference cited to SCR]; Conférence des juges de paix magistrats du Québec v Quebec (Attorney General), 2016 SCC 39, [2016] 2 SCR 116.

18 See New Brunswick Broadcasting, supra note 17 at 353, Lamer CJ and at 374-378, McLachlin J; R v Mercure, [1988] 1 SCR 234, 48 DLR (4th) 1; British Columbia (Attorney General) v Canada (Attorney General); An Act respecting the Vancouver Island Railway (Re), [1994] 2 SCR 41, 114 DLR (4th) 193.

19 RSC 1985, c S-26.

20 See Reference re Supreme Court Act, ss 5 and 6, 2014 SCC 21 at para 94, [2014] 1 SCR 433 [Supreme Court Act Reference].

21 Ibid at para 91.

22 Ibid at para 94. See paras 90-95.

23 CA 1982, supra note 5, part V.

24 British North America (No.2) Act, 1949 (UK), 12, 13 \& 14 Geo VI, c 81.

25 CA 1867, supra note 2, part VI.

26 CA 1982, supra note 5, ss 44-45.

27 Reference re Senate Reform, 2014 SCC 32 at paras 32, 45-48, [2014] 1 SCR 704 [Senate Reform Reference].

28 See New Brunswick Broadcasting, supra note 17.

29 Eurig Estate (Re), [1998] 2 SCR 565, 165 DLR (4th) 1 [Eurig Estate cited to SCR].

$30 \mathrm{Ibid}$ at 582-583. In other words, Justice Major took for granted that because the provincial legislatures' jurisdiction over "the constitution of the province" had been moved from the federalprovincial division of powers to the "Procedure for Amending Constitution of Canada", section 45 had to be read "in association with subsection 52(1) of the Constitution Act, 1982", as though the legislatures' lawmaking power under the former subsections 91(1) and 92(1) had become a (real) constitutional amending power.

31 See Warren J Newman, "Defining the 'Constitution of Canada' Since 1982: The Scope of the Legislative Powers of Constitutional Amendment Under Sections 44 and 45 of the Constitution Act, 1982" (2003) 22 SCLR (2d) 423 at 491. See also Adam Dodek, "Uncovering the Wall Surrounding the Castle of the Constitution: Judicial Interpretation of Part V of the Constitution Act, 1982" in Emmett Macfarlane, ed, Constitutional Amendment in Canada (Toronto: University of Toronto Press, 2016) 42 at 55.
32 Reference re Agricultural Products Marketing, [1978] 2 SCR 1198, 84 DLR (3d) 257.

33 Eurig Estate, supra note 29 at 582.

34 See Eurig Estate, supra note 29 at 582-583.

35 CA 1867, supra note 2, ss 55, 90.

36 See Senate Reform Reference, supra note 27 at paras 46-48, 90, 94.

37 CA 1982, supra note 5, part II.

38 Ibid, s 35.1.

39 Constitution Amendment Proclamation, 1983, SI/84-102, (1983) C Gaz II, E-9.

40 CA 1982, supra note 5, s 38.

41 See Senate Reform Reference, supra note 27 at paras 95-110.

42 See also Christa Scholtz, "Part II and Part V: Aboriginal Peoples and Constitutional Amendment," in Emmett Macfarlane, ed, Constitutional Amendment in Canada (Toronto: University of Toronto Press, 2016) 85; Bryan Schwartz, First Principles, Second Thoughts: Aboriginal Peoples, Constitutional Reform and Canadian Statecraft (Montreal: Institute for Research on Public Policy, 1986), at 134-35.

43 CA 1982, supra note 5, s 52(3).

44 Richard Albert, "The Difficulty of Constitutional Amendment in Canada” (2015) 53:1 Alta L Rev 85 at 108.

45 Canada Act, 1982, supra note 4.

46 See generally Roy J Romanow, John D Whyte \& Howard A Leeson, Canada-- Notwithstanding: The Making of the Constitution 1976-1982, 25th Anniversary Edition, (Toronto: Thomson Carswell, 2007); Gil Rémillard, "Historique du rapatriement" (1984) 25:1 Les Cahiers de droit 15.

47 Re: Objection by Quebec to a Resolution to amend the Constitution, [1982] 2 SCR 793 at 806, 140 DLR (3d) 385.

48 See HLA Hart, Essays in Jurisprudence and Philosophy, (Oxford: Clarendon Press, 1983) at $309 \mathrm{ff}$.

49 See Santi Romano, The Legal Order, translated and ed by Mariano Croce (Abingdon, UK: Routledge, 2017).

50 Canada Act, 1982, supra note 4, s 2.

51 British North America Act, 1871 (UK), 34 \& 35 Vic, c 28. Renamed by CA 1982, supra note 5, s 53(1).

52 British North America Act, 1930, (UK) 20 \& 21 Geo V, c 26, s 24.

53 CA 1982, supra note 5, s 58.

$54 \mathrm{Ibid}$, ss 38, 41, 43, 48.

$55 \mathrm{Ibid}, \mathrm{s} 47$.

56 Ibid, s 46(1). See Sibbeston v Canada (AttorneyGeneral), [1998], 48 DLR (4th) 691, 1988 CanLII 5673 (NWTCA) [Sibbeston]. 
57 CA 1982, supra note 5, s 48.

58 Ibid, s 49.

59 While we seem not to find it in federal statutes, various types of exceptions to the sheer political existence of the office of first minister is now found in all provincial statutory laws except that of Alberta: see the Quebec Executive Power Act, CQLR, c E-18; the Ontario Executive Council Act, RSO 1990, cE.25, the British Columbia Constitution Act, RSBC 1996, c 66; the Saskatchewan Legislative Assembly and Executive Council Act, 2007, SS 2007, c L-11.3, ss 59(4), 61(4)); Executive Government Administration Act SS 2014, c E-13.1, s 28(1); the Newfoundland and Labrador Executive Council Act, SNL 1995, c E-16.1, the Nova Scotia Executive Council Act, RSNS 1989, c 155, ss 6(1), 10; the Prince Edward Island Executive Council Act, RSPEI 1988, c E-12; and the New Brunswick Executive Council Act, RSNB 2011, c 152, ss 5(1), $6(2), 6(2.1), 7(2)$. I am anything but sure all of these provincial provisions dealing with the office of "First Minister," "Premier," or "Prime Minister" do not unconstitutionally amend the supreme law relating to the office of Lieutenant Governor of a province within the meaning of s 41(a) CA 1982.

60 For a contrary, enthusiastic reading, see Patrick Taillon \& Alexis Deschênes, "Une voie inexplorée de renouvellement du fédéralisme canadien: lobligation constitutionnelle de négocier des changements constitutionnels" (2012) 53:3 Les Cahiers de droit 461.

61 Quebec Secession Reference, supra note 17 at para 68.

62 See Teskey $v$ Canada (Attorney General), 2014 ONCA 612; O’Donohue $v$ Canada, 2005 CanLII 6369, 2005 CarswellOnt 951 (CA); Motard c Canada (Procureure générale), 2016 QCCS 588 [Motard].

63 See Supreme Court Act Reference, supra note 20 and corresponding text.

64 CA 1982, supra note 5, s 41.

$65 \mathrm{Ibid}, \mathrm{s}$ 43. See Senate Reform Reference, supra note 27 at paras 42-44, 91-94, which rejects the Quebec Court of Appeal's interpretation in Potter c Québec (Procureur général du), 2001 CanLII 20663 at paras 33-49, [2001] RJQ 2823. See also Guy Tremblay, "La portée élargie de la procédure bilatérale de modification de la Constitution du Canada" (2011) 41:2 Revue générale de droit 417; José Woehrling, "Le recours à la procédure de modification de l'article 43 de la Loi constitutionnelle de 1982 pour satisfaire certaines revendications constitutionnelles du Québec” in Pierre Thibault, Benoît Pelletier \&
Louis Perret, eds, Les mélanges Gérald-A Beaudoin: Les défis du constitutionnalisme, (Cowansville, QC: Les Éditions Yvon Blais Inc, 2002) 449; Stephen A Scott, "Pussycat, Pussycat or Patriation and the New Constitutional Amendment Processes" (1982) 20:2 UWO L Rev 247.

66 CA 1982, supra note 5, s 43.

67 Ibid, s 16.1, which was added by the Constitution Amendment, 1993 (New Brunswick), SI/9354, using CA 1982, supra note 5, s 43 . See also Tremblay, supra note 66.

68 See Campbell v Canada (Attorney General), 49 DLR (4th) 321, 1988 CanLII 3043 (BCCA).

69 See Senate Reform Reference, supra note 27.

70 See ibid; Constitutional Question Act (Re), 78 DLR (4th) 245, 1991 CanLII 405 (BCCA).

71 See Supreme Court Act Reference, supra note 20 and corresponding text.

72 See Sibbeston, supra note 56.

73 See ibid.

74 CA 1982, supra note 5, s 42.

75 Ibid, s 38(2).

76 Irrespective of the issue of whether compensation under section 40 is only available when the right to withdraw granted by subsection 38(3) has been exercised - we do not see why, but most if not all of our fellow Canadian constitutionalists seem to think so - the category of amendments to which section 40 applies does not overlap with those described by subsection $42(1)$.

77 CA 1982, supra note 5, s 38(1)(b).

78 See Sibbeston, supra note 56; Canada (Prime Minister) v Penikett, 45 DLR (4th) 108, 1987 CanLII 145, (YCA).

79 CA 1867, supra note 2, s 92(16).

80 See Re: Anti-Inflation Act, [1976] 2 SCR 373, 68 DLR (3d) 452.

81 See ibid; $R v$ Crown Zellerbach Canada Ltd, [1988] 1 SCR 401, 49 DLR (4th) 161. See also Ontario Hydro $v$ Ontario (Labour Relations Board), [1993] 3 SCR 327, 107 DLR (4th) 457; R v Hydro-Québec, [1997] 3 SCR 213, 151 DLR (4th) 32.

82 SC 2013, c 6.

83 See Motard, supra note 62.

84 CA 1982, supra note 5, s 44.

85 Supra note 27 at para 75.

86 Ibid at paras 75, 78.

87 For a contrary, enthusiastic reading of the SCC's opinion in this reference, see Sébastien Grammond, "The Protective Function of the Constitutional Amending Formula" (2017) 22:2 Rev Const Stud 171. 
